\title{
Knowledge and Practice on Reproductive Heath Rights among Married Women in Nepal
}

\section{${ }^{1}$ Rajesh Kumar Yadav, ${ }^{2}$ Nand Ram Gahatraj, ${ }^{3}$ Dipendra Kumar Yadav, ${ }^{1}$ Sujan Babu Marahatta}

\author{
${ }^{1}$ Manmohan Memorial Institute of Health Sciences, Kathmandu, Nepal \\ ${ }^{2}$ LA GRANDEE International College, Pokhara University \\ ${ }^{3}$ School of Health and Allied Sciences, Pokhara University, Nepal
}

\begin{abstract}
Reproductive health rights ensure that people are able to have satisfying and safe sex life and that they have the capacity to reproduce with freedom to decide, when and how often to do so. This study aimed to assess the knowledge and practices on reproductive health rights among madhesi married women. A descriptive cross-sectional study was conducted among 384 madhesi married women of reproductive age in Sarlahi district conducted from July 2014 to December 2014. Data were entry in Epidata software and analyzed by SPSS 20 version. Of the total 384 respondents most of them (39.3\%) were of age group 25-35 years from different ethnic groups. Most were simple illiterate (65.6\%) and housewife (60.9\%) very few of respondents were knowledge about reproductive health rights (37\%) and not statistical significant relationship with level of knowledge and level of practice $\left(\chi_{1}^{2}=2.036, p=0.154\right)$. Level of knowledge was statistically significant relationship with educational level $\left(\chi_{4}^{2}=43.983 p<0.001\right)$. Use of FP services have statistically significant relationship with Age group $(p<0.001)$. The level of knowledge and level of practice on RHRs is still very low in Madhesi women.
\end{abstract}

Keywords: Reproductive health rights; Madhesi women; practice.

Corresponding address: Rajesh Kumar Yadav, Manmohan Memorial Institute of Health Sciences, Kathmandu, E-mail: rky0013@gmail.com

\section{INTRODUCTION}

Reproductive Health (RH) is a state of complete physical, mental and social well-being (not merely the absence of disease and infirmity) in all matters relating to the reproductive system and its functions and processes. ${ }^{1}$ Reproductive rights embrace certain human rights that are already recognized in national laws, international human rights documents and other consensus documents. ${ }^{2}$ Reproductive health rights ensure that people are able to have satisfying and safe sex life and that they have the capacity to reproduce with freedom to decide, when and how often to do so. ${ }^{3}$ Situation of reproductive health and thus the quality of life of females are not satisfactory in developing countries. Unequal access to information, care and basic health services, early marriage (17.2 years), deeply-rooted believes, the prevailing social and cultural structures, low literacy rate $(42.0 \%)$, the unmet need of family planning (24.6\%), and unsafe abortion and delivery conducted by untrained personnel $(80.0 \%)$ are further increasing the health risk for women. Altogether, $20.0 \%$ of the global burden of women's health is related to sexual and reproductive health problems. ${ }^{4}$ Reproductive and sexual health rights are rights of all people, regardless of age, gender and other characteristics. That is, people have the right to make choices regarding their own sexuality and reproduction, provided that they respect the right of others. ${ }^{5}$ Women have the right to the enjoyment of the highest attainable standard of physical and mental health. The enjoyment of this right is vital to their life and wellbeing and their ability to participate in all areas of public and private life. ${ }^{6} \mathrm{~A}$ human rights-based approach is based on seven key principles: availability, accessibility, Acceptability and quality of facilities and services, participation, equality and non discrimination, and accountability. ${ }^{7}$ Reproductive rights must be protected, promoted and fulfilled if sexual and reproductive health outcomes are to be improved, particularly for the poor and vulnerable. ${ }^{8}$ Socioeconomic and demographic characteristics have played important roles in the growth of knowledge about reproductive health rights. ${ }^{9}$ The economic and democratic development has significant positive effects on levels of gender equality. The level of social development plays a prominent role in promoting reproductive rights. ${ }^{10}$

Basically in the rural areas different intervention have been done by nongovernmental organization but Women from 
the Madhesi community could not come forward due to social and religious restriction and they are deprived of education, information technologies which make un aware and vulnerable to domestic violence gender discrimination Reproductive health and its problem is still regarded as a taboo in Nepalese society as well as in Madhesi community so women in the absence of proper information, awareness and services suffer adverse RH.

Sarlahi district has the comparatively lower literacy rate (41.7\%) in the comparison to other district. Among them, women are less literate than men. Poor development of physical infrastructure, High fertility rate (5.06) and birth spacing ( $<26$ month) is also very low. Reproductive health rights have been identified as one of the major public health problem in Sarlahi of Nepal. Therefore, with an aim to assess the knowledge and practices on reproductive health rights among Madhesi married women.

\section{METHODS}

The study was a community based cross sectional study carried out on reproductive age group of the madhesi married women. This study protocol reviewed and approved from the department of public health of LA GRANDEE International College. Additional permission for the study was obtained from the district health office of Sarlahi district of Nepal and village development committee. Verbal informed consent was taken from the participant before initiate the interview. Anonymity and confidentiality of the individual were maintained. The study populations were madhesi married women of different VDC of Sarlahi districts of Nepal.

The sample size was determined by using the following formula as shown below

$$
\mathrm{n}=\frac{\left(\mathrm{z}^{2} \mathrm{pq}\right)}{\mathrm{d}^{2}}
$$

Where,

$$
\begin{aligned}
\mathrm{n}= & \text { Desired sample size } \\
\mathrm{Z}= & \begin{array}{l}
\text { Value of standard normal distribution in } 1.96 \text { level } \\
\text { of significant with } 95 \% \text { confidence interval }(\mathrm{CI})
\end{array} \\
\mathrm{P}= & \begin{array}{l}
\text { proportion }=50 \%, 50 / 100=0.5 \text { (There is no proper } \\
\text { available literature references was found on this } \\
\text { topic so } 50 \% \text { of prevalence was considered for }
\end{array} \\
& \text { sample size calculation.) } \\
\mathrm{q}= & (1-\mathrm{p})=(1-0.5)=0.5 \\
\mathrm{~d}= & \text { desirable error }=5 \%,=0.05 \\
\mathrm{n}= & \frac{(1.96)^{2}}{(0.05)^{2}}
\end{aligned}
$$

the calculated sample size was 384 . Study was conducted from July to December 2014 by using multistage sampling method. The data were collected using a semi structure questionnaire with face to face interview. Pretesting of study was conducted on $10 \%$ of the sample size in dharmpur VDC of rautahat districts of Nepal. Data were entered in Epidata software and analyzed by using SPSS 20 version software.

\section{RESULTS}

Of the 384 female respondents of reproductive age group form different ethnic groups and religions Table 1 shows that majority $39.3 \%$ (151) of respondents were of age group 25-35 years where mean was 29.59 years, 7.576 years, minimum age was 15 years and maximum age was 49 years. Majority 99.2\% (381) of respondents were Hindu and rest was Christian. Majority 63\% (242) of respondents were disadvantage non dalit terai caste. Majority $65.6 \%$ (252) of respondents were illiterate. Majority 95.3\% (366) of respondents got arranges marriage followed by $2.9 \%$ (11) love marriage, where as $0.8 \%$ (3), $0.8 \%$ (3) and $0.2 \%$ (1) court marriage, force marriage and child marriage respectively. Majority 51\% (196) of respondents had nuclear family, $60.9 \%$ (234) were house. Nearly third quarter $72.4 \%$ (55) of respondents had a monthly income of NRs $<9500$ thousand followed by $13.2 \%$ (10) monthly income of NRs 9500 to 14500 thousand and $14.5 \%$ (11) of respondents had NRs $>14500$ thousand.

Table 1: Distribution of respondents by sociodemographic and background Information $(n=384)$

\begin{tabular}{|l|l|l|}
\hline \multicolumn{1}{|c|}{ Variables } & Frequency (n) & Percentage (\%) \\
\hline Age & & \\
\hline 15-25 Years & 110 & 28.6 \\
\hline 25-35 Years & 151 & 39.3 \\
\hline 35-45 Years & 100 & 26 \\
\hline More than 45 Years & 23 & 6 \\
\hline Mean age 29.59 Years, SD 7.576, Max 49 Years and Min 15 Years \\
\hline Religion & \multicolumn{2}{|c|}{} \\
\hline Hindu & 381 & 99.2 \\
\hline Christian & 3 & 0.8 \\
\hline Ethnicity & & \\
\hline $\begin{array}{l}\text { Disadvantage non } \\
\text { dalit Terai caste }\end{array}$ & 242 & 63 \\
\hline Dalit & 93 & 24.2 \\
\hline Upper caste groups & 49 & 12.8 \\
\hline $\begin{array}{l}\text { Respondent's } \\
\text { educational status }\end{array}$ & & \\
\hline Illiterate & 252 & 65.6 \\
\hline Primary & 73 & 19 \\
\hline Secondary & 38 & 9.9 \\
\hline & & \\
\hline
\end{tabular}




\begin{tabular}{|l|l|l|}
\hline Higher secondary & 11 & 2.9 \\
\hline Bachelor & 10 & 2.6 \\
\hline Types of marriage & & \\
\hline Arrange marriage & 366 & 95.3 \\
\hline Love marriage & 11 & 2.9 \\
\hline Court marriage & 3 & 0.8 \\
\hline Force marriage & 3 & 0.8 \\
\hline Child marriage & 1 & 0.2 \\
\hline Family types & & \\
\hline Nuclear & 196 & 51 \\
\hline Joint & 188 & 49 \\
\hline Occupation & & \\
\hline Housewife & 234 & 60.9 \\
\hline Agriculture and housewife & 96 & 25.1 \\
\hline Agriculture & 25 & 6.5 \\
\hline Small business & 12 & 3.1 \\
\hline NGO/INGO Job & 7 & 1.8 \\
\hline Daily wages labor & 6 & 1.6 \\
\hline Government Job & 4 & 1 \\
\hline Monthly income in NRs & & \\
\hline$<9500$ & 55 & 72.4 \\
\hline $9500-14500$ & 10 & 13.2 \\
\hline$>14500$ & 11 & 14.5 \\
\hline
\end{tabular}

Table 2 describes of respondents by their knowledge and practice on components of reproductive health rights. Third fourth $63 \%$ (242) of respondents did not know about reproductive health right. Majority $65.4 \%$ (251) of respondents answered best marriage age of their daughter is above 18 Years. Percentage distribution due to multiple respondents the Majority $60.7 \%$ (159) of respondents had physical violence followed by $60.3 \%$ (158) dowry violence where as $40.5 \%$ (106), $23.3 \%(61), 0.8 \%$ (2) and $2.3 \%$ (6) sexual violence and others (Touchability and man dominate) violence and did not know about violence with them respectively. Majority $87.2 \%$ (335) of respondents heard about family planning, more than half $57 \%$ (217) of respondents answered that both husband and wife decide the birth of child. Nearly Third fourth $58 \%$ (214) of respondents answered both husband and wife decided child spacing followed by $33.9 \%$ (125) husband, $31.7 \%$ (117), and $16.5 \%$ (61) self and father and mother. Percentage distribution due to multiple respondents the majority $46.7 \%$ (175) of respondents answered both husband and wife decided about FP and during this study period majority $56.5 \%$ (213) of respondents used FP services.

Among those who were checked up heath during

reproductive health problems (RHPs) majority $74.1 \%$ (260) of respondents asked husband to check up during RHPs and $34.2 \%$ (120) self. Majority 91.7\% (352) of respondents had poor knowledge on RHRs and $21.4 \%$ (82) of respondents has satisfactory level of practices.

Table 2: Distribution of respondents by their knowledge and practices on components of reproductive health rights

\begin{tabular}{|c|c|c|}
\hline Variables & \multirow{2}{*}{ Frequency (n) } & \multirow[b]{2}{*}{ Percentage (\%) } \\
\hline $\begin{array}{c}\text { Heard about reproductive } \\
\text { health rights }(n=384)\end{array}$ & & \\
\hline Yes & 142 & 37 \\
\hline No & 242 & 63 \\
\hline \multicolumn{3}{|l|}{$\begin{array}{l}\text { Best marriage age of } \\
\text { their daughter }(n=384)\end{array}$} \\
\hline Below 18 years & 13 & 34.6 \\
\hline Above 18 Years & 251 & 65.4 \\
\hline \multicolumn{3}{|l|}{$\begin{array}{l}\text { Types of violence in } \\
\text { Madhesi society }(n=262) *\end{array}$} \\
\hline Physical violence & 159 & 60.7 \\
\hline Stigma and discrimination & 158 & 60.3 \\
\hline Dowry violence & 106 & 40.5 \\
\hline Sexual violence & 61 & 23.3 \\
\hline Touchability \& man dominate & 2 & 0.8 \\
\hline Don't Know & 6 & 2.3 \\
\hline \multicolumn{3}{|l|}{ Heard about FP $(n=384)$} \\
\hline Yes & 335 & 87.2 \\
\hline No & 149 & 12.8 \\
\hline \multicolumn{3}{|l|}{$\begin{array}{l}\text { Who decided the birth of } \\
\text { child*(n=381) }\end{array}$} \\
\hline Both husband and wife & 217 & 57 \\
\hline Husband & 129 & 33.9 \\
\hline Self & 114 & 29.9 \\
\hline Father in law and mother in law & 69 & 18.1 \\
\hline Family member & 14 & 3.7 \\
\hline God gift & 4 & 1 \\
\hline \multicolumn{3}{|l|}{$\begin{array}{l}\text { Who decided birth } \\
\text { spacing* }(n=369)\end{array}$} \\
\hline Husband and wife both & 214 & 58 \\
\hline Husband & 125 & 33.9 \\
\hline Self & 117 & 31.7 \\
\hline Father in law and mother in law & 61 & 16.5 \\
\hline \multicolumn{3}{|l|}{$\begin{array}{l}\text { Decision makers on family } \\
\text { planning* }(n=375)\end{array}$} \\
\hline Husband and wife both & 175 & 46.7 \\
\hline Husband & 160 & 42.7 \\
\hline Self & 124 & 33.1 \\
\hline Father in law and mother in law & 102 & 27.2 \\
\hline
\end{tabular}




\begin{tabular}{|l|c|c|}
\hline Friends & 31 & 8.3 \\
\hline Neighbor and family member & 2 & 0.5 \\
\hline $\begin{array}{l}\text { Use of family planning methods } \\
\text { (n=377) }\end{array}$ & & \\
\hline Yes & 213 & 56.5 \\
\hline No & 164 & 43.5 \\
\hline $\begin{array}{l}\text { With whom they asked for } \\
\text { RHPs check up*(n=352) }\end{array}$ & & \\
\hline Husband & 260 & 74.1 \\
\hline Self & 120 & 34.2 \\
\hline Father and mother in law & 100 & 28.5 \\
\hline Family members & 67 & 19.1 \\
\hline Neighbor & 3 & 0.9 \\
\hline level of Knowledge (n=384) & 352 & 91.7 \\
\hline Poor level of Knowledge & 32 & 8.3 \\
\hline Satisfactory level of Knowledge & & \\
\hline level of Practices (n=384) & 302 & 78.6 \\
\hline Poor level of Practices & & 21.4 \\
\hline Satisfactory level of Practices & & \\
\hline
\end{tabular}

\section{*Multiple Responses}

Table 3 shows that the distribution of the variables and associations of the factors with the knowledge level and practice level of RHRs of the madhesi married women are present in table 3. It was found that poor level of practice $79.5 \%$ among poor level of knowledge and 68.5\% among satisfactory level of knowledge. Level of practice have not statistically significant relationship with level of knowledge on RHRs ( $p>0.05$ ). It was found that level of knowledge on RHRs was $13.4 \%$ among radio/TV and $39.1 \%$ among newspaper. Level of knowledge on RHRs have statistically significant relationship with Sources of information $(\mathrm{p}<0.001)$.

Table 3: Distribution of respondents by association of their level of knowledge and level of practice on RHRs and level of knowledge and sources of information.

\begin{tabular}{|c|c|c|c|c|c|c|c|c|c|}
\hline \multirow{3}{*}{\multicolumn{2}{|c|}{$\begin{array}{c}\text { Level of } \\
\text { Knowledge }\end{array}$}} & \multicolumn{6}{|c|}{ Level of Practice } & \multirow{3}{*}{$\begin{array}{c}\text { Test } \\
\text { of significance }\end{array}$} & \multirow{3}{*}{ P-Valu } \\
\hline & & \multicolumn{2}{|c|}{$\begin{array}{c}\text { Poor } \\
\mathrm{n}=302(78.6 \%)\end{array}$} & \multicolumn{2}{|c|}{$\begin{array}{c}\text { Satisfactory } \\
\mathrm{n}=82 \\
(21.4 \%)\end{array}$} & \multicolumn{2}{|c|}{ Total } & & \\
\hline & & n & $\%$ & n & $\%$ & n & $\%$ & & \\
\hline \multirow{2}{*}{\multicolumn{2}{|c|}{$\begin{array}{c}\text { Poor } \\
\text { Satisfactory }\end{array}$}} & 280 & 79.5 & 72 & 20.5 & 352 & 100 & \multirow{2}{*}{$\chi_{1}^{2}=2.036$} & \multirow{2}{*}{0.154} \\
\hline & & 22 & 68.8 & 10 & 31.2 & 32 & 100 & & \\
\hline \multirow{3}{*}{\multicolumn{2}{|c|}{$\begin{array}{c}\text { Sources of } \\
\text { information }\end{array}$}} & \multicolumn{6}{|c|}{ Level of knowledge } & \multirow{2}{*}{$\begin{array}{c}\text { Test } \\
\text { of significance }\end{array}$} & \multirow[b]{2}{*}{ P-Value } \\
\hline & & \multicolumn{2}{|c|}{$\begin{array}{l}\text { Poor } \\
\mathrm{n}=35 \\
(91.7)\end{array}$} & \multicolumn{2}{|c|}{$\begin{array}{c}\text { Satisfactory } \\
\mathrm{n}=\mathbf{3 2} \\
(\mathbf{8 . 3} \%)\end{array}$} & \multicolumn{2}{|c|}{ Total } & & \\
\hline & & n & $\%$ & II & $\%$ & II & $\%$ & \multirow{3}{*}{$\chi_{1}^{2}=14.35$} & \\
\hline \multirow{2}{*}{ Radio/TV } & Yes & 174 & 86.6 & 27 & 13.4 & 201 & 100 & & \multirow{2}{*}{0.001} \\
\hline & No & 178 & 97.3 & 5 & 2.7 & 183 & 100 & & \\
\hline \multirow{2}{*}{ Newspaper } & Yes & 14 & 60.9 & 9 & 39.1 & 23 & 100 & \multirow{2}{*}{$\chi_{1}^{2}=30.37$} & \multirow{2}{*}{0.001} \\
\hline & No & 338 & 93.6 & 23 & 6.4 & 361 & 100 & & \\
\hline
\end{tabular}

\section{DISCUSSION}

In this study about $37 \%$ of respondents were aware about the reproductive health rights. Study conducted by Kaphle $\mathrm{M}^{4}$ majority $68.3 \%$ of respondents had knowledge about reproductive right which is higher than this study because the research was conducted in Kathmandu capital of Nepal. As per our finding, $56.5 \%$ of respondents answered the right marriage age of $>20$ years. Kaphle $\mathrm{M}^{4}$ reported that majority $(83.2 \%)$ of the respondents were aware about the right marriage age of $>20$ years. Which is higher than this study because due to the traditional practice of doing early marriage in Terai region. In this study about $87.2 \%$ of respondents knew about any method of FP. study by Malalu $\mathrm{PK}^{11}$ reported that $80.8 \%$ of respondents knew any method of family planning which is similar with this study.

In the current study showed that, three fifth $57 \%$ of respondents made decision by herself and husband of birth of child. Study by Kaphle $\mathrm{M}^{4}$ showed that $50.7 \%$ both husbands and wives decision of birth of child which is similar to this study.

In this study about $55.2 \%$ of respondents had radio/TV as sources of information RHRs. Study by Adinew YM ${ }^{5}$ reported that majority $80.4 \%$ of respondent's sources of information for RH was radio/TV. This is higher than this study because the respondents of adinew have higher accessibility of radio/ TV.

In this study there is also no statistical significant association between women's attitudes toward best marriage age of their daughters and age of the respondents [1.102, $\mathrm{p}=0.603]$. Study by Kaphle $\mathrm{M}^{4}$ reported there is not statistical significant association between women's attitudes towards best marriage age of their daughters and age of the respondents $[\mathrm{p}=0.130]$ which is similar to this study.

\section{CONCLUSION}

In this study knowledge on reproductive health rights among participants were low. Three fifth of respondents were not aware about the reproductive health rights. Three fifth of respondents had perceived physical and dowry violence. Almost of respondents got marriage with decision of both fathers and mothers. There is strong statistically significant relationship with sources of information (radio/TV, newspaper) and level of knowledge on RHRs. Practice was found higher in respondents having satisfactory knowledge. Development partners and government authorities should be conducted programs on raising awareness on reproductive health rights throuygh mass media i.e. radio, television, and newspaper. There should be implemented the empowerment program for Madhesi women. 


\section{ACKNOWLEDGEMENT}

We are thankful to the research approval committee at LA GRANDEE International college for permission to conducted this study and not forgetting the participants who are participated in this study and they had given valuable information.

\section{REFERENCES}

1. Inter-agency Working Group on Reproductive Health in Crises. Inter-Agency Field Manual on Reproductive Health in Humanitarian Settings. Inter-agency Working Group on Reproductive Health in Crises, 2010.

2. Griffin S. Literature review on sexual and reproductive health rights: universal access to services, focussing on East and Southern Africa and South Asia. Panos, London: Department for International Development, 2006.

3. Dhaher E. Reproductive health human rights: women's knowledge, attitude, and practices toward their reproductive health rights in Palestine, 2008.

4. Kaphle M. Awareness and Utilization of Reproductive Rights Among the Women of Reproductive Age in Kapan VDC, Nepal. JHAS, 2013; 3(1):5-9.

5. Adinew YM, Worku AG, Mengesha ZB. Knowledge of reproductive and sexual rights among University students in Ethiopia: institution-based cross-sectional. BMC International Health and Human Rights, 2013; 13:12.

6. The Fourth World Conference on Women. Beijing Declaration and Platform for Action Beijing, 4 to 15 September 1995.

7. Bustreo F, Hunt P, World Health Organization. Women's and children's health: evidence of impact of human rights. World Health Organization, 2013.

8. Sexual and reproductive health and rights. Department for International Development, July 2004. Available from: http:// www.hivpolicy.org/Library/HPP000499

9. Hossain K, Mondal NI, Akter MN. Reproductive Health Rights of Women in the Rural Areas of Meherpur District in Bangladesh. J Reprod Infertil, 2011; 12(1):23-32.

10. Pillai VK, Gupta R. Reproductive rights approach to reproductive health in developing countries. Global Health Action, 2011; 4:8423 - DOI: 10.3402/gha.v4i0.8423.

11. Malalu P, Alfred K, Too R. Determinants of use of modern family planning methods: A Case of Baring North District, Kenya, 2014; 2(2): Available from: http://article.sciencepublishinggroup.com/pdf/10.11648.j.sjph.20140205.18.pdf

12. Beekel A. Awareness and determinants of family planning practice in Jimma, Ethiopia, 2006; (53): Available from: http://www.ncbi.nlm.nih.gov/pubmed/17083415 